\title{
Establishing the Malay Landscape Elements through Islamic Garden Perspective
}

\author{
Nur Huzeima Mohd Hussain ${ }^{1 *}$, Khalilah Hassan ${ }^{2}$, Norizan Mt Akhir ${ }^{3}$ \\ 1,2, 3 Faculty of Architecture, Planning \& Surveying, Universiti Teknology MARA, Seri Iskandar Campus, 32610 Perak, Malaysia
}

\begin{abstract}
Beliefs and interpretations from the Islamic concept have influenced the emergence and extensions of many landscape designs including the Malay landscape. This paper reviews the significant relation between the Malay landscape and Islamic garden concept through established references. The main intention is to identify, analyzing and establishing the landscape elements, design characteristic and their functions as the research attributes. This paper uses the imagery evidence from the Quran to support the study analyses and discussions. The conclusions will lead towards all possible dimensions of Islamic Malay landscape in cultural, traditional and sustainability context for future resilient.
\end{abstract}

(C) 2016. The Authors. Published for AMER ABRA by e-International Publishing House, Ltd., UK. This is an open access article under the CC BY-NC-ND license (http://creativecommons.org/licenses/by-nc-nd/4.0/).

Peer-review under responsibility of AMER (Association of Malaysian Environment-Behaviour Researchers), ABRA (Association of Behavioural Researchers on Asians) and CE-Bs (Centre for Environment-Behaviour Studies), Faculty of Architecture, Planning \& Surveying, Universiti Teknologi MARA, Malaysia.

Keywords: Malay; landscape; element; Islamic concept

\section{Introduction}

The Holy Quran has brought with its revelation over the past 14th century, many concepts relating the man and nature. One of the concepts that relate to this relationship is 'garden'. 'Garden' were mentioned 164 times in the Quran, which showed the importance of garden to man. From early living, the garden has played a major role in human civilization and 'Islamic Garden' was recorded to be one of the early gardens which representing the earthly image of 'Paradise' (Kamil \& Yunos, 2015). The Islamic Garden which acknowledged during the 7th century through the establishment of Persian Garden. Islamic garden has inspired and influenced the emergence and extensions of many landscape designs such as the Moorish garden, European garden, Mexican landscape and Asian landscape including the Malay landscape.

\footnotetext{
* Corresponding author. Tel.: +605- 3742000

E-mail address: nurhu154@perak.uitm.edu.my
}

2398-4287 @ 2016. The Authors. Published for AMER ABRA by e-International Publishing House, Ltd., UK. This is an open access article under the CC BY-NC-ND license (http://creativecommons.org/licenses/by-nc-nd/4.0/).

Peer-review under responsibility of AMER (Association of Malaysian Environment-Behaviour Researchers), ABRA (Association of Behavioural Researchers on Asians) and CE-Bs (Centre for Environment-Behaviour Studies), Faculty of Architecture, Planning \& Surveying, Universiti Teknologi MARA, Malaysia.

DOI: http://dx.doi.org/10.21834/e-bpj.v1i3.363 
The understanding of both the Islamic garden concept and Malay landscape are vast. Particularly on the background history and culture, design inspirations, conceptual development, and implementations. However, the relation and discussion between both concepts are still vague. This is a brief conceptual paper reviewing both concept; the Malay landscape and Islamic garden singularly and comparatively in order to pursuit the development and preservation of their significant image and identity. The main concern is regarding to the issues of lack information and explanation on how the Malay and Islamic landscape connects in both physical and spiritual concepts. Without further research and justification between these concepts, the significant relation with slowly being forgotten and replaced by the contemporary approach. This paper reviews the significant relationship between the Malays and Islamic concept through established references. It envisions a contribution not only for the fundamental investigation but also supporting Mohit (2013) analysis on how environment helps towards improving the society quality of life.

The main intention is to investigate, understand and document the fundamental findings in which are important for future discourse on Islamic and Malay contemporary landscape design. This study highlighted the landscape elements, plants selections and their functions as the research attributes. The reviews also adopted qualitative method by utilizing theory, concepts and approaches. The acquired data will be described in descriptive form and comparative analysis in which are manually documented in MS Word and Excel. The exploration conducted was to identify the character, similarities and differences between both landscape designs. The aims are to establish potential attributes that would be reasonably reliable in enhancing the Islamic-Malay landscape design in future.

Furthering such discourse and exploration are central to the discussion as it involved theoretical and practical understandings of how the Islamic concept influenced the Malay landscape design. In particular, this paper will also address on the verse from Quran that can support clarifications and evidence. Therefore, this paper will primarily present the relation, together with identifying a comparison between both the Islamic concept and Malay landscape in Malaysia contemporary. The conclusions will lead towards all possible dimensions of Islamic-Malay landscape in cultural, traditional and sustainability context for future undertakings.

\section{The Malay Culture}

The cultural landscapes of the Malays were originated from the regions of the Malay Archipelago, in which has brought with them their traditional cultural values and lifestyles, as well as wisdom from their early settlements in the Malay Peninsula. Traditionally, man has become almost self-sufficient by utilizing the use of the land immediately around them for everyday living (Hussain \& Byrd (2012). This integration has developed the cultural landscape into a modified one (Appleton, 1975). Studies by Kaplan (1975) also support this by discovering that people often prefer settings that include nature due to the landscape natural characteristics that change through time and seasons, resulting in an exciting and adventurous background in their daily lives. This discovery explains the preference of humans in modifying their natural resources to fulfill both the physical and spiritual needs of a community as a whole (Ani A., et al., 2012). Rosley et. al (2013) added that 'human remains a strong attachment to the surrounding as well as intrinsically connected to one another in perceiving the environment' which supported the biophilia theory by Kahn (1996). The Malays are known for their culturally-rich heritage and inherited values which were shaped by their beliefs and norms through their daily activities.

However, after the arrival of Islam reached Malay Peninsula in the 13th century, the Malays began to adopt, adapted and responded well to their environment, especially to the landscape resources (Zainal, 1994). Zainal (1994) added that the Islamic customs of the Malays later has helped to determine the norms of behaviour, values and beliefs of the traditional Malay society, where the Islamic principles substantially shape the pattern of family relations and individual behavior. His findings were also supported by Majid et. al (2013), Anuar (2006) and Teh \& Nasir, (1997), regarding the relationship between human behavior and the traditional Malay surrounding in everyday life are much dictated by the teachings of the Holy Quran and the Prophet's hadiths. 


\section{The Malay traditional landscape}

The Malay traditional landscape was documented to be predominantly agricultural which supported the basic human need such as the staple food of rice fields, tapioca Bush and coconut groves (Hussain \& Byrd (2012). Meanwhile, Julaihi (2006) emphasizes the pattern of settlements in Malaysia were traced back to the agglomeration of huts in the fruit orchards, the paddy fields 'island houses', tin mining 'kongsis', fisherman's houses along the rivers and also in the peri-urban houses (Julaihi Wahid, 2006). Also, Julaihi highlighted the culture, politics and daily activities of the people as important factors that helped to shape the physical environment of early settlements in Malaysia. Besides these areas, the natural landscape was mainly covered in forest or as coastal areas (Ismail NA, 2005). These areas inherited the characteristics of a natural and traditional landscape that represents the relationship between human and their surroundings. In other words, traditionally, the Malays planted their surrounding with foods and basic needs such as plants for material, tools and medicine (Hussain \& Byrd (2012), Maliki (2010)).

The Malay traditional landscape which comprises of herb or kitchen gardens located in backyards (Hussain \& Byrd (2012)) have actually embraced the Kaplans' study on natural experiences found that nearby nature, which defines everyday places such as backyards, as having virtually as much restorative power as nature (Krinke, 2005) . These have been planted to support basic needs of daily living. In particular, the traditional values regarding natural resource use are still practiced among rural people and especially by the older generation (Hussain \& Byrd, 2011). As a result of development, the long-standing traditional landscape features of paddy fields, vegetable farms, and orchards are expanding and are still essential to meeting the demands of socio-economic progress and population growth (Abdullah, 2011).

The Malay Landscape typology

The Malay landscape typologies show the pattern and character of landscape design in a Malay traditional house compound. It correlated the spaces within both areas, the outdoor and indoor living space. In general, the Malay landscape typology consisted of four main compounds surrounded the house. That includes:

\subsubsection{Front Compound \\ 2.2.2. Side Right and Left Compound \\ 2.2.3. Rear Compound}

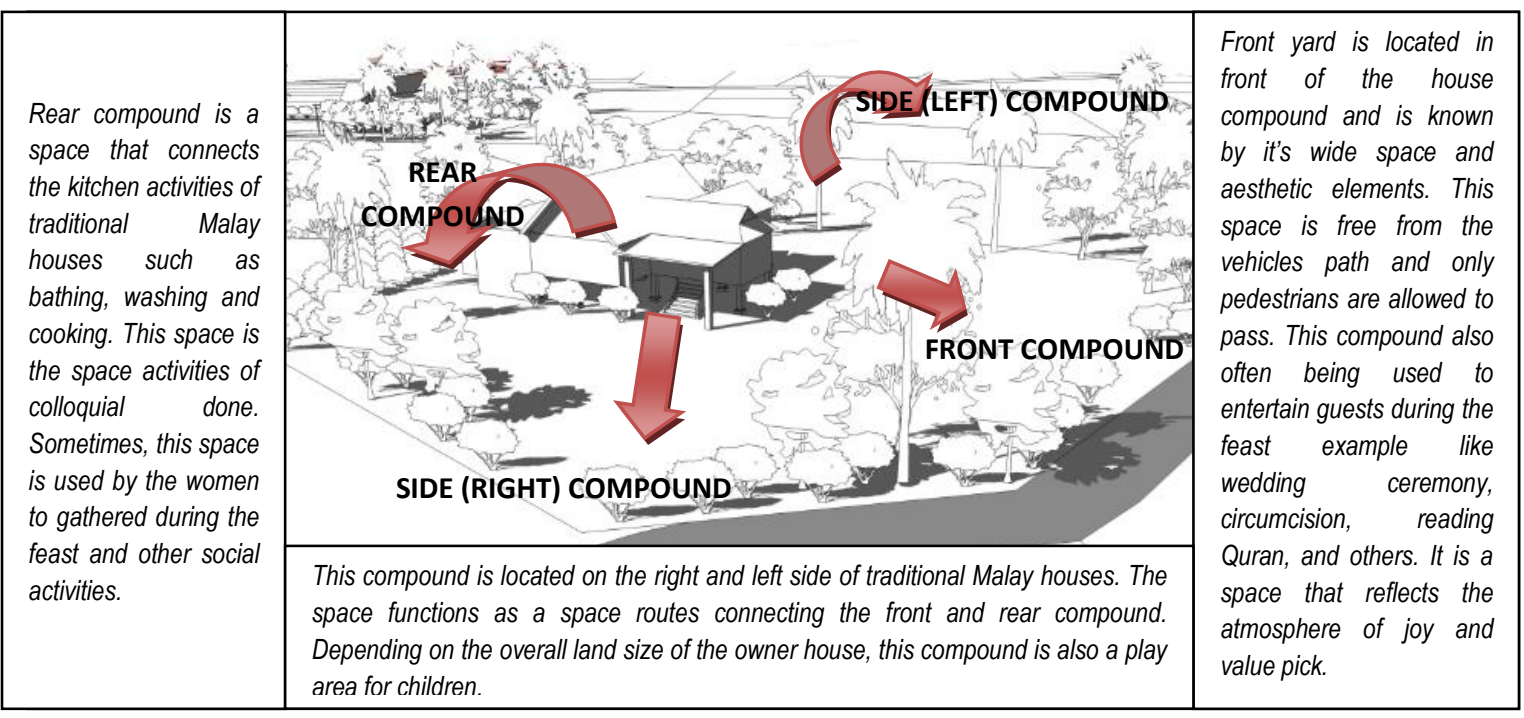

Theoretically, these typologies are parallel with the origin theory of the man and nature relationship. Moreover, this traditional landscape was also composed of a variety of attributes such as aesthetic values: landscape personality 
as an image; the utilitarian need for resources and materials; edibility of self-grown food and perhaps fulfillment of a social interaction activity.

Landscape Elements in the Malay Traditional Landscape Elements

The Malay traditional landscape is a tolerant to the external spaces or traditional Malay house compound. The landscape surrounding the house reflects the simplicity of the traditional Malay society based on their beliefs and philosophy (Ismail \& Said, 2002). Thus, the surrounding of the Malay traditional house also relates to its internal activities. Essentially, all elements have interest and function, other than a way of life and taboos that play a role in the placement of landscape elements in the house surrounding of traditional Malay society (Maliki, 2008). In general, landscape development in traditional Malay society is to achieve harmony with the environment.

\section{Softscape / Plants elements}

According to McHarg (1976), there is a direct and indirect relationship between human and plants. In the Malay landscape, plants and humans are so intimately linked. These communities commonly use plants for dietary (food consumption), utilities such as materials for construction, medicinal, ritual, dyes and cosmetics (Adnan \& Othman (2010).

Adnan \& Othman (2010) in their article entitled 'The relationship between Plants and Malay Culture', together with previous researchers including Wong ( 2005, 2009 ), Salleh et.al (2009) and Hussain (2004) have listed about 70 species of edible herbs which are called 'ulam' that are frequently planted and used in the Malays kitchen. The species are namely such as 'daun tenggek burung' (Euodia ridleyi), betel leaf (Piper sarmentosum), shining bush (Peperomia pellucid), 'pegaga' (Centella asiatica) and other traditional vegetables such as spinach (Amaranthus oleaceus), lady's finger (Hibiscus esculentus), as well as herbs such as pandan leaves, lemon grass, curry leaf and others. Besides herbs, there are also several fruits trees being mentioned by Hussain (2004) including banana tree (Musa sp.), mango, guavas, grapes, pumpkin, jackfruit, melon and rambutan.

The Malays love to be associated with a variety of lovely home-cooked meals, which justify the importance of domestic raw food supplies in this community. An edible garden is a must in most domestic gardens in the world, and it is implemented by the Malays as well. Most of the samples studied allocate edible gardens in their compounds at the backyard as the Malays highly value privacy.

In conclusions, the functions and benefits of the softscapes or plants as an elements in Malay landscape incudes:

(i) Flowering plants for aesthetic

(ii) Medicinal plants for healings

(iii) Edible / Kitchen garden for cooking

(iv) Palms for boundary demarcation

(v) Exotic/Aesthetic plants for beautifications

(vi) Big trees for shades

The understanding on the relationship between plants and the Malay culture helps to preserve and conserve traditional cultures in which could protect the heritage and prolong it for future subsistence.

\section{Hardscape elements}

Besides the soft scapes elements, the Malay landscape also composed by the compound built-elements, as another main elements of the Malay landscape composition. The hard landscape can be categories as the man-made elements. It is the design of an additional element that complements the design of a landscape garden. The example of these man-made elements as been discussed by Zakaria et al. (2013), Hussain \& Ahmad (2012) and Ani A. et al. (2012) are such as the kebuk padi (paddy storage), perigi (well), tempayan (vase), kolah (tank), pasu (pot), 'pelantar'/'wakaf' and other landscape furniture including chairs, swings and ponds). The importance of perigi or well has been a key feature in a Malay garden since the early settlements. During the pre-independence era, it was used as an instant water source right up to the 1990's when water crisis occurred in Melaka. The tempayan (vase) and kolah (tank) were also identified as supporting elements in handling that situation (Ani A., et al., 2012). 
Hussain \& Ahmad (2012) added the hardscape lighting that has also played significant role in the landscape setting, especially for supplying enough capacity of light during night time. This is not only giving comfort to the residents but also alarm from any possibility danger. The usage of garden lights, lamps, LED light was found to have a high tendency utilized by the community, especially during the festive season. Furthermore, the use of these elements will increase the benefits and beauty of a site specifically for the residential of Malay contemporary community.

\section{Aesthetics in Malay Landscape}

The Malay landscape emphasises beauty as part of their culture. The aesthetic demand begins from the front areas of a house, followed to the rear and up to the backyard. Aesthetic is important as the Malay culture are very particular in celebrating their guest. Therefore the Malays would design their front areas or compound as beautiful as possible in order to attract guest and neighbours to come to their house. This value is parallel to their culture of welcoming people to their house as it would bring good reward by the Al Mighty and keep good relationship with the community or their neighbours.

\section{Islamic Garden Concept: Imagery from the Quran}

In this section, this paper discusses the understanding of Islamic garden concept by adopting the explanation of the imagery description from the Quran. The descriptions of gardens begin as early as the expressions of paradise being mentioned in the Holy Quran. The Quranic verse has consistently conveyed the imagery impression of greenery, beauty, serenity, flowing canals, overwhelming foods which describing garden (Kamil \& Yunos, 2015). For example, in the following verse illustrates the heaven, earth, plants and beauty;

"Allah has created the heavens and the earth, and He sends you down rain from the sky with it We cause to grow well-planted orchards, Full of beauty and delight" (Surah An-Naml: 99)

With regards to this relationship between the garden and 'paradise' from the Quran, this paper focuses on the significant elements of the 'paradise' that have been used to compose a garden which is closely representing the Islamic garden. For example, as mentioned in the above verse of Surah An-Naml: 99, the 'rain', 'orchards', 'beauty' and 'delight' are some of the components describing 'heaven' or 'paradise'. Further discussions on the components are as the followings;

\section{The Paradise Garden}

Since the arrival of Islam, as a religion in the 7th century, gardens have been described as a metaphor of Paradise or Al-Janna (The Garden). Every time 'heaven' or 'paradise' is mentioned in the holy book of Quran, there is an explanation of flowing water and fruit bearing trees, signifying their prominence to man. The reward for good deeds according to the Quran is a place of shaded trees, flowing water, gardens with sweet fruits and fragrant flower (Kamil \& Yunos, 2015). Meanwhile, Nur Hafizah et al. (2014) describes 'heaven' as a symbol of an area that includes a space advantage, where there are plants, floral, fruits and also the animal.

However, no man can see the 'paradise' until the Judgment Day. Allah Almighty has presented a very detailed description of paradise in Quran. Upon reading Quran one can have an imaginary picture of paradise. For example, there are a few verses of Quran relating to the description of paradise.

"(Here is) a Parable of the Garden which the righteous are promised: in it are rivers of water incorruptible; rivers of milk of which the taste never changes; rivers of wine, a joy to those who drink; and rivers of honey pure and clear. In it there are for them all kinds of fruits; and Grace from their Lord..." (Surah Muhammad 47:15)

"[They will sit] on gold-encrusted thrones of happiness, reclining upon them, facing one another in [love]. Immortal youths will wait upon them with goblets, and ewers, and cups filled with water from unsullied springs by which their minds will not be clouded and which will not make them drunk; and with fruit of any kind that they choose, and with flesh of any fowl that they may 
desire."(Surah Al Waqia 56:15-21)

There are so many other verses of Quran in which paradise has been portrayed in a lovely manner. Those who believe in Allah, his messenger and have lead the life on earth to the will of Allah will be given the right by Allah almighty to enter paradise as been mentioned in the following verse;

"And [accompanying them will be their] companions pure, most beautiful of eye, like unto pearls hidden in their shells. [This will be] a reward for what they did [during life]. No empty talk will they hear there, nor any call to sin, but only the tiding of inner soundness and peace." (Surah Al Waqia 56:22-26)

\section{Principles \& Landscape Elements}

The discussions about 'paradise', Islamic garden and its concept are varies. Many researchers have raised attention on the specific design concept while others begins to relate the concept within a wider context. According to Kamil \& Yunos (2015) study has reviewed the theoretical background of elements engaged in the Islamic Garden such as trees and water and environment such as calmness, beauty and balance. For example, Kamil \& Yunos (2015) analyses the philosophical implications of the garden elements in the Quran through references being potrayed in a surah; in this case they anaysed surah Al-Waqiah. With the aid of the understanding in 'Tafsir of the Fizilal', those elements and principles of paradise imagery of Surah Al-Waqiah are listed in the table below:

Table 3.2: The typical Quranic paradise imagery derived from Surah Al-Waqiah (Kamil \& Yunos (2015)

\begin{tabular}{ccc}
\hline No. & Element / Ambient & Characteristic \\
\hline 1 & Facilities & Impressive, serenity, exciting \\
2 & Comfort and balance & Amazing, Sensational \\
3 & Water, Fruit, Animal, & Never-ending, lush and \\
& Plantation & Sreenery \\
4 & People, Society & Noble, worthy, educated \\
\hline
\end{tabular}

From the Surah Al-Waqiah findings, a paradisiacal garden is described as an unlimited paradise and secures space, with diverse trees planted in specific locations, accessed to through eight gates. Therefore, Kamil \& Yunos (2015) emphasized the findings as the Islamic Garden principles based on applying the ideological principle in Islamic faith and Quranic paradise imagery.

\section{Plants in Quran}

Plants in Quran have been conveyed in many ways. According to Eskandari \& Jalali (2013) reviews on plants in Quran, they discussed that the plants were not only used as food but also as ornamental plants (the grain in the blade; and aromatic herbs, Surah Al-Rahman; 12), shaded plants (near them shall be its shade, Surah AlInsan;14), used as an index of scale for example mustard to predicate accuracy (In Surah Al-Luqman; 16 said: 'My son, if it should be but the weight of one grain of mustard seed, and though it be on a rock, or in the heavens, or in the earth, Allah shall bring it. surely, Allah is the subtle, (Surah Al-Luqman; 16) or as punishment for guilty humans named as "Zzaqqum" grows from the bottom of hell (Surah As- Saafat; 64)(Eskandari \& Jalali, 2013).

\section{Features and characteristic of design from the Quran}

The 'aesthetics', according to the Quran, are the beauty presented by the character of Allah (God). Aesthetic was also mentioned to be the natural beauty of the heavens and the earth. For example, the Quran refers beauty specifically for sky lighting. This shows that decorate the light can also be important in human and is one of the beautification. 
In other 'beautiful' verses of the Qur'an, the creation of man has been attributed. Colour, consistency and proportions of such features has been refered to Quran. Also, Quran also refers to a beautiful woman and her beauty to keep these commands. God created man and a special creation. Also, new man is inherent to this industry. In fact, all the attributes of God in the creation of man and thus all these attributes used in humans are reflected. Then, all these characters are reflecting for human.

In general, by regarding institutional elements and features from the Quran and architectural aesthetics as the manmade environment, the following results can be made. The first step in examining the aesthetic view of the Qur'an, is knowing the words that have been used in this area. Beauty, faith, ornament, stated, 'Bahjat', 'Zokhrof', 'Tasvil', 'Hubbak', 'Tabaroj', 'Noor', and 'Leuven' are the words used in Quran as the beauty of nature in heaven and earth, all created by God.

Plants and water are a factor in the vitality and beauty of the characteristics of man-made beauty. Color, consistency and proportions of features that the Quran has mentioned. The beauty of the architecture can be given to the needs and size of the human and a combination of nature and architecture, means the combination of natural beauty and man-made beauty (art) that is not in conflict with each other. Architecture, based on this elementary composition and characteristics mentioned in the definition is unique. Therefore, the development of eternal meaning and truth and beauty in art and architecture begins for the audience.

\section{Interpreting the Malay Landscape through Islamic concept}

Based on the previous discussions on the Malay landscape and Islamic garden, this paper further reviews on how these generic concepts correlates between one another. The similarities together with the differences bet both concept has been raised by Osman (1989). He highlighted the occurrence of assimilation process in Malay society after Islam presence has lead to a huge impact to daily life till Malay and Islam could not be part which there is a degree someone said that if an individual entering Islam, then that person has joining into the Malay race (Osman, 1989).

Moreover, Nur Hafizah et. al (2014) has also begun to convey the Malay landscape concept and elements through the image of Islamic garden which are depicted from the image of paradise garden. In addition he added that paradise or heaven were used to symbolisesas an area that include a space advantage, where there are plants, floral, fruits and also animal. As seen in plant organisation in Malay society' house area, there are several same speculation as gardens that are visualised in heaven as all of it have certain function that are beneficial for their daily life. For example, the functions and advantages of plants in Malays landscape that are significant with Islamic concept were interpreted through the followings surah or hadith from the Quran.

\section{Plant cultivate in Malay landscape involved fruit trees, herbs or medicines, for kitchen basics}

There have been many verses explaining the functions of plants as resources for food, medicine and survival. The Quran has repeatedly uses the words corps, livestock, fruits and food as been mentioned in Surah Ali-Imran (3:14) and Surah Al An'am 6: 99)

"It is He Who sends down water (rain) from the sky, and with it We bring forth vegetation of all kinds, and out of it We bring forth green stalks, from which We bring forth thick clustered grain. And out of the date palm and its spate come forth clusters of dates hanging low and near, and gardens of grapes, olives and pomegranates, each similar (in kind) yet different (in variety and taste). Look at their fruits when they begin to bear, and the ripeness thereof. Verily! In these things there are signs for people who believe." (Surah Al-An'am: 99).

\section{Beauty or aesthetic value in design}

Some of society thought that Islam did not care about the beauty for there is no basis in Quran and also as-sunnah about it. The truth is the Islam itself already too beautiful because Allah is too beautiful and He loves beauty and it is said in hadith that a human duty on earth, one of them is to beautify the earth (Fatos, 2011). "Allah is indeed 
beautiful and He loves the beauty." (Hadith riwayat Muslim). Allah s.w.t's mighty can be seen through His creations' beauty so that every creature bow to this one and only creator. It is however, stated in surah An-Naml as below:

It is understandable that the beauty not only beautiful and delicious to one's sight, but it also contain hidden meanings. Islam's beauty could be seen in the way Muslims celebrates guests to their home, and in landscape context, Malay society usually cultivate beautiful and bright colour flowers around their home to bring out 'sense of welcoming' (Abdullah Sani, A., in Nur Hafizah et. al, 2014). The sentence of "Whereby We cause to grow wonderful gardens full of beauty and delight? It is not in your ability to cause the growth of their trees" clearly shows beautiful expression carries the soul composed meaning besides it cool the eyes whose seen it (Nur Hafizah et. al, 2014).

Besides that, Quran also described that:

"And you see the earth barren, but when We send down water (rain) on it, it is stirred (to life), it swells and puts forth every lovely kind (of growth)." (Surah Al-Hajj 22: 5). This verse also had clearly state that plants and crops are significant elements in the existing beauty of this earth. Thus, we can see here how the connection of the flora was utilized to produce the image of beauty not only in heaven but also on earth. So does flowers that produce good fragrant are mostly plant in Malay landscape also symbolise Islamic elements (Abdullah Sani, A., in Nur Hafizah et. al, 2014).

Together with beauty, Fatos (2011) has correlates it with fragrant. There is a saying that roses fragrant are Prophet Muhammad s.a.w's odour and the symbol of beauty (Fatos, 2011). Besides, Nur Hafizah et al (2014) has discussed the implementation of frangrant and flowers between the Islamic teachings that encourage the Muslims to wear fresh or fragrant odour with the Malay society's culture who also love to cultivate plant that produce fragrant plant, not only for celebrating the guest but also as perfume for ladies and putting them (flowers) on their hair. Some of the favourite flower used are 'kesidang' plant (Canangium scortechinii), 'jasmine', 'kemuning' (Murraya paniculata, commonly called 'Orange Jessamine'), 'cempaka' (Gardenia spp.), roses and others.

The practise of appreciating fragrant from flowers could be value with paradise visual which is also said to have a pleasant fragrant. This relates with Imam Ibnu Qayyim r.a explain that: "It is true Allah had shown to His followers of this world some effect reflecting paradise's characteristic, for example fragrant and delicious smell, cool, beautiful scenery, good quality fruits, all the heavenly joy and leisure."

\section{Plants symbolises good deeds}

In the Malay cultures, there are a practise of giving present or gift to people which symbolises their appreciation and a kind of attending or serving their guest. While in Islam, there are also urgency and encouragement in giving charity or 'sadaqah' to people in which were counted as a good deeds. Besides that, Malay society culture concept of love to help could also be seen in Malay landscape typology. The Malay landscapes prioritise their guest more than themselves. They composed their 'front compound' especially with the aesthetic flowers to create the sense of welcoming and inviting. This will intentionally attract visitors and would become an activities that would enabled them to share it with their neighbours. This will subsequently develop a good relationship within the neighbourhood /community (Hussain \& Byrd, 2012). As it is quoted in Quran:

"O! You who believe! Spend of the good things which you have (legally) earned, and of that which We have produced from the earth for you, and do not aim at that which is bad to spend from it, (though) you would not accept it save if you close your eyes and tolerate therein. And know that Allah is Rich (Free of all wants), and Worthy of all praise." (Surah Al-Baqarah 2: 267).

Besides flowers and aesthetic plants, fruits and other edible plants are also essential in Malay landscape that will not only valuable as food and resources but also could contribute to be an alternative as to exchange or provide present for guest or neighbours. The importance of sharing these resources or the so called 'rezeki' are stated in the hadith, which was narrated by Anas bin Malik r.a, Rasulullah s.a.w says:

"Not a Muslim cultivates a tree or plants with a type of plant, but then it was eaten by birds, human or livestock, except it will be charity to him/her".'(Hadith Riwayat Muslim) 


\section{Prohibited wasted}

On the other hand, apart from encouraging good deeds that are parallel between the Malay landscape and Islamic concept, there are also justifications on things that the people should avoid. Nur Hafizah et al (2012) has identified the one of the practise in Malay landscape is not allowing any waste. She added, the Malays only implemented things that would benefits their daily needs whether it is directly or indirectly. For example, application of the cultivated pandan leaves is not limited only for a function, but much more such as cake's fragrant extract, cake colouring and also as flower mixture for wedding ceremony, berzanji (a type of song to praise Prophet Muhammad), and completion of Quran (Nur Hafizah et al (2012). Moreover, waste are prohibited as been mentioned in the following verse;

"Verily, spendthrifts are brothers of the Satan, and the Satan is ever ungrateful to his Lord"(Surah Al-Isra 17: 27).

Therefore, it is understandable why Allah forbids His followers from doing any waste. It is practically align in Malay landscape, in which every plant cultivated has its own value or functions.

\section{Integrating Culture and Beliefs towards Future Resilient}

There is a significant culture that influences the way people perceive and use the resources of their environment (Cohn, 1988). These relationships display the importance of mutual connection between man and nature to continuously survive and make a living.

This paper are aligned with Kamil \& Yunos (2015) and Nur Hafizah et. al (2014) ideas on how the general Islamic garden principles and Quranic paradise imagery derived from verse of Quran can help people to establish systems, regulations, attitudes and views in order to understand and control their worldly life in accordance with their needs, region and time. The ideas of implementing the Islamic garden into the garden in Malaysia is perceived as relevant and encourage effort to support the governance approach in creating an Islamic environment (Kamil \& Yunos, 2015). This paper also interpreted the significant connections between the implementations of Malay landscape functions and elements with the Islamic garden that was supported by the related verses of the holy Quran.

Therefore, this paper foresee a potential mutual adaptation between man and nature through the reflection from the Quran will be a good platform for establishing the Malay-Traditional landscape together with the Islamic garden concept towards future considerations. The concern is to establish the value of the landscape not only for human survival but also towards the ecological resilient in the environment.

\section{Acknowledgements}

This paper is part of the extension in demonstrating the understanding of cultural landscape; in particular between the Malay Landscape and the Islamic Garden Concept. This paper is fully based on the interest and initiative by the members of Landscape Architecture Department from UiTM Perak, Malaysia.

\section{References}

Adnan, N., \& Othman, N. (2012). The relationship between plants and the Malay culture. Procedia-Social and Behavioral Sciences, 42, 231-241.

Pourjafar, M. R., \& Vasigh, B. (2008). Study of various Landscape Elements in Quran with respect to Soreh-e AIRahman. Bagh-I-Nazar SpringSummer 2008, Volume 5, Number 9; Page(s) 23 To 34.

Ani, A., Mohamed, N., \& Rahman, N. A. (2012). Socio-Cultural Influences in The Composition of Traditional Malay House Compounds in Rural Melaka. ALAM CIPTA, International Journal of Sustainable Tropical Design Research and Practice, 5(1). 
Bemanian, M. R., Ansari, M., Noqrehkar, A., \& Vasiq, B. (2011). Elements of Landscape Architecture In The Holy Quran. Soffeh Summer 2011, Volume 21, Number 53; Page(s) 5 To 14.

Carneiro, M. J., Lima, J., \& Silva, A. L. (2015). Landscape and the rural tourism experience: identifying key elements, addressing potential, and implications for the future. Journal of Sustainable Tourism, 23(8-9), 1217-1235.

Kamil, S. M., \& Yunos, M. Y. M. (2015). Establishing Malaysia Islamic Garden Based On Quranic Paradise Imagery: Descriptive Analysis From Tafsir Surah Waqiah. Advances in Environmental Biology, 9(23), 115-119.

Hussain, M., Huzeima, N., \& Ahmad, S. (2009). Malay landscape: typical design for contemporary house at Desa Wawasan, Unpublished thesis for RMI UITM

Hussain, N. H. M., \& Ahmad, S. (2012). Landscape Design for Malay Contemporary House at Desa Wawasan. Procedia-Social and Behavioral Sciences, 42, 182-189.

Hussain, N. H. M., \& Byrd, H. (2012). Towards a compatible landscape in Malaysia: An idea, challenge and imperatives. Procedia-Social and Behavioral Sciences, 35, 275-283.

Ismail, N. A., \& Ariffin, N. F. M. (2015). Longing for culture and nature: The Malay Rural Cultural Landscape 'Desa Tercinta'. Jurnal Teknologi, 75(9).

Majid NHA, Hamidi MH, Denan Z. (2013), Cultural Sustainability and Islamic Perspectives in Introducing a Cohesive Retirement Village for Muslims, Procedia - Social and Behavioral Sciences 85 ( 2013 ) 164 - 178, AcE-Bs 2013 Hanoi ASEAN Conference on Environment-Behaviour Studies Hanoi Architectural University, Hanoi, Vietnam, 19-22 March 2013 "Cultural Sustainability in the Built and Natural Environment"

Maliki, N. Z. (2008). Kampung/landscape: rural-urban migrants' interpretations of their home landscape. The case of Alor Star and Kuala Lumpur (Doctoral dissertation, Lincoln University).

Mazehan, S. M., Shuib, B. K., \& Hashim, H. (2013). Value of Rural Landscape from Public Perspectives. In Proceedings of the International Conference on Social Science Research, ICSSR (pp. 4-5).

McHarg, I. L. (1967) Design With Nature. New York: John Wiley \& Sons, Inc.

Mohit MA (2013), Quality of Life in Natural and Built Environment An Introductory Analysis, AicQoL 2013 Langkawi AMER International Conference on Quality of Life Holiday Villa Beach Resort \& Spa, Langkawi, Malaysia, 6-8 April 2013 "Quality of Life in the Built and Natural Environment", Procedia - Social and Behavioral Sciences 101 ( 2013) 33-43

Rosley MS, Lamit H, Abdul Rahman SF.(2013) Perceiving the Aesthetic Value of the Rural Landscape through Valid Indicators, Procedia - Social and Behavioral Sciences, 85 ( 2013 ) 318 - 331, AcE-Bs 2013 Hanoi ASEAN Conference on Environment-Behaviour Studies Hanoi Architectural University, Hanoi, Vietnam, 18-21 March 2013 "Cultural Sustainability in the Built and Natural Environment"

Shokrpour, M, \& Fakherian, P. (2015). Evaluation Of Aesthetics In Architecture From The Perspective Of Quran. Cumhuriyet Science Journal, 36(4), 1611-1616.

Shuib, K. B., Clark, I., \& Hashim, H. (2008). Exploring heritage value of a Malay landscape.

Zakaria, A. Z., Salleh, I. H., \& Rashid, M. S. A. (2013). Landscape Furniture Present in the Ancient Malay Garden According to Old Manuscripts and their Effects on the Formation of Malay Garden Design Concept Model in Malaysia. Procedia-Social and Behavioral Sciences, 91, 28-35. 